\title{
Clinical characteristics, treatment and outcome of 28 oral haemangiomas in pediatric patients
}

\author{
Cristina Bonet-Coloma ${ }^{1}$, Ignacio Mínguez-Martínez ${ }^{2}$, Cristina Palma-Carrió ${ }^{3}$, Sónnica Galán-Gil ${ }^{\text {, }}$, María \\ Peñarrocha-Diago ${ }^{4}$, Juan-Manuel Mínguez-Sanz ${ }^{5}$
}

\footnotetext{
${ }^{1}$ Master of Oral Surgery and Implantology, Valencia University Medical and Dental School, Valencia, Spain

${ }^{2}$ Master of Oral Surgery and Implantology, Professor of Oral Surgery. Cardenal Herrera-CEU University, Valencia, Spain

${ }^{3}$ Student of Master of Oral Surgery and Implantology, Valencia University Medical and Dental School, Valencia, Spain

${ }^{4}$ Professor Assistant of Oral Surgery. Master of Oral Surgery and Implantology, Valencia University Medical and Dental School, Valencia, Spain

${ }^{5}$ Head Service of Maxillofacial Surgery, University La Fe Hospital, Valencia, Spain
}

Correspondence:

Clínica Odontológica,

Gascó Oliag, 1,

46021-Valencia (Spain)

mariapenarrocha@uv.es

Received: $13 / 10 / 2009$ Accepted: 06/03/2010

\author{
Bonet-Coloma C, Mínguez-Martínez I, Palma-Carrió C, Galán-Gil S, \\ Peñarrocha-Diago M, Mínguez-Sanz JM. Clinical characteristics, treat- \\ ment and outcome of 28 oral haemangiomas in pediatric patients. Med \\ Oral Patol Oral Cir Bucal. 2011 Jan 1;16 (1):e19-22. \\ http://www.medicinaoral.com/medoralfree01/v16i1/medoralv16ilp19.pdf \\ Article Number: $16792 \quad$ http://www.medicinaoral.com/ \\ (C) Medicina Oral S. L. C.I.F. B 96689336 - pISSN 1698-4447 - eISSN: 1698-6946 \\ eMail: medicina@medicinaoral.com \\ Indexed in: \\ Science Citation Index Expanded \\ Journal Citation Reports \\ Index Medicus, MEDLINE, PubMed \\ Scopus, Embase and Emcare \\ Indice Médico Español
}

\begin{abstract}
Objective: To present a large series of oral haemangiomas in children, analyzing the clinical characteristics, treatment and outcome of oral haemangiomas in 28 children.

Material and Methods: We conducted an observational retrospective study, reviewing medical records with clinical diagnosis of haemangioma between 1990 and 2006 at the Children's Maxillofacial Surgery Service of the Hospital Universitario la Fe, Valencia. All patients with a clinical, radiographic, pathologically confirmed diagnosis of oral haemangioma were included.

Results: The study included 28 patients (19 females and 9 males) with a mean age of 4.27 years (range $0-14$ years). Nine were congenital haemangioma. The most frequent location of oral haemangioma was in the lip with 23 cases, followed by three cases in the tongue and 2 in the buccal mucosa. The mean diameter of the lesion was $1.67 \mathrm{~cm}$ (range $1-3 \mathrm{~cm}$ ). The mean duration of the lesion was 6.3 months (range 1 month to 5 years). Of the 28 haemangiomas, 13 were surgically removed, 2 were treated with embolization and 13 disappeared spontaneously. The mean follow up was 2.7 months (1-8 months). There were no cases of recurrence.

Conclusions: Haemangiomas usually present in children, and can be seen from birth. They have a predilection for females. They are uncommon in the oral cavity. In the oral region, the most common location is the lip. Most congenital haemangioma regress spontaneously without treatment. The treatment of choice is surgical excision of the lesion.
\end{abstract}

Key words: Haemangioma, pediatric patients, oral cavity. 


\section{Introduction}

In 1982, Mulliken and Glowacki (1), classified vascular lesions as haemangiomas or vascular malformations. The haemangioma is a benign proliferation of endothelial cells common in the head and neck (2) and relatively rare in the oral cavity (3). They usually occur during the neonatal period, grow during the first year of life and regress slowly. They predominate in females. The most frequent location for oral haemangiomas is the lip (4-6). Treatment is needed for complications such as ulcerations, infections, bleeding or obstruction of the airway (6). According to different authors $(3,4,6)$, the treatment of choice is surgical excision of the lesion.

After reviewing the articles published between 1999 and 2009 on haemangiomas in the oral region, 7 publications were found (Table 1) (3-9). Some authors $(4,5)$ studied maxillofacial tumours in pediatric patients specifying the incidence of haemangiomas, while others have published isolated case reports $(3,7,9)$. We felt it would be interesting to analyze the oral haemangiomas a large sample of pediatric patients the Children's Maxillofacial Surgery Service of the Hospital Universitario la Fe, Valencia.

The aim of this study is to analyze the clinical characteristics, treatment and outcome of haemangiomas in the oral cavity in 28 pediatric patients.

\section{Material and Methods}

A retrospective observational study was performed, reviewing the medical records of pediatric patients (aged 0-14 years) with clinical diagnosis of haemangioma between 1990 and 2006 in the Children's Maxillofacial Surgery Service of the Hospital Universitario la Fe, Valencia.

Patients with clinical and radiographic diagnosis of oral haemangioma were included. Cases where the pathologic diagnosis of the excised lesions did not confirm the clinical diagnosis of oral haemangioma, and cases with incomplete records were excluded. Thirty-five medical records with diagnosis of oral haemangioma were reviewed, of which seven were excluded ( 2 because the pathological diagnosis did not confirm the diagnosis of haemangioma, and 5 for incomplete records). Twentyeight patients were included in the study.

The following data were recorded: sex, age, location and size of the lesion, duration (time from first appearance of lesion until the date of diagnosis), treatment depending on the size and location of the lesion (extirpation, monitoring or embolization Ethibloc ${ }^{\circledR}$ (Johnson \& Johnson, Madrid, Spain), length of follow-up (from date of diagnosis to date of discharge or last revision) and recurrences.

Table 1. Oral haemangiomas in children published since 1999.

\begin{tabular}{|c|c|c|c|c|c|c|c|}
\hline Author & Year & $\begin{array}{c}\mathbf{N}^{\mathbf{0}} \\
\text { Cases } \\
\end{array}$ & Sex & Age & Location & Size (cm) & Treatment \\
\hline Tanaka et al. (4) & 1999 & 25 & - & $\begin{array}{l}6 \text { months - } \\
15 \text { years }\end{array}$ & $\begin{array}{c}14 \text { lip } \\
6 \text { tongue } \\
4 \text { oral mucosa } \\
1 \text { gingiva } \\
\end{array}$ & - & Surgical Extirpation \\
\hline Açikgöz et al. (3) & 2000 & 1 & M & 13 years & Mucosa of palate & - & Surgical Extirpation \\
\hline $\begin{array}{c}\text { Van Doorne et al. } \\
(7)\end{array}$ & 2002 & 1 & $\mathrm{~F}$ & 4 months & Upper lip & - & $\begin{array}{c}\text { Oral Corticoids + Surgical } \\
\text { Extirpation }\end{array}$ \\
\hline $\begin{array}{l}\text { Al-Khateeb et al. } \\
\text { (5) }\end{array}$ & 2003 & 28 & - & $<18$ years & $\begin{array}{c}16 \text { lower lip } \\
5 \text { upper lip } \\
5 \text { tongue } \\
1 \text { oral mucosa } \\
1 \text { floor of mouth }\end{array}$ & - & - \\
\hline McHeik et al. (6) & 2005 & 8 & $\begin{array}{l}7 \mathrm{~F} \\
1 \mathrm{M}\end{array}$ & $\begin{array}{l}22-60 \\
\text { months }\end{array}$ & $\begin{array}{l}6 \text { upper lip } \\
2 \text { lower lip }\end{array}$ & Range 1-5 & Early Surgical Extirpation \\
\hline Selim et al. (8) & 2007 & 2 & $2 \mathrm{~F}$ & $\begin{array}{l}10 \text { weeks } \\
\text { and } 16 \text { years }\end{array}$ & $\begin{array}{l}\text { Upper lip } \\
\text { Tongue }\end{array}$ & $\begin{array}{c}3 \times 3 \\
3.5 \times 2\end{array}$ & $\begin{array}{c}\text { Intralesional injection } \\
\text { with sclerosing agent ( } 5 \% \\
\text { ethanolamine oleate) }\end{array}$ \\
\hline $\begin{array}{c}\text { Kutluhan et al. } \\
(9)\end{array}$ & 2008 & 1 & $\mathrm{~F}$ & 7 years & Tongue & $4 \times 2$ & Plasma scalpel \\
\hline
\end{tabular}

M: Male

F: Female 
Table 2. Congenital oral haemangiomas in this study.

\begin{tabular}{|c|c|c|c|c|c|}
\hline Case & Sex & Location & Size (cm) & Treatment & $\begin{array}{c}\text { Follow-up } \\
\text { (months) }\end{array}$ \\
\hline $\mathbf{1}$ & M & Tongue & 2 & Monitoring & 4 \\
\hline $\mathbf{2}$ & F & Lower lip & 1.5 & Extirpation & 5 \\
\hline $\mathbf{3}$ & F & Buccal mucosa & 2 & Monitoring & 2 \\
\hline $\mathbf{4}$ & F & Lower lip & 1.5 & Extirpation & 2 \\
\hline $\mathbf{5}$ & M & Lower lip & 1.5 & Monitoring & 2 \\
\hline $\mathbf{6}$ & F & Tongue & 1 & Monitoring & 4 \\
\hline $\mathbf{7}$ & M & Upper lip & 1 & Monitoring & 4 \\
\hline $\mathbf{8}$ & F & Lower lip & 1 & Monitoring & 3 \\
\hline $\mathbf{9}$ & F & Upper lip & 1 & Monitoring & 2 \\
\hline
\end{tabular}

M: Male

F: Female

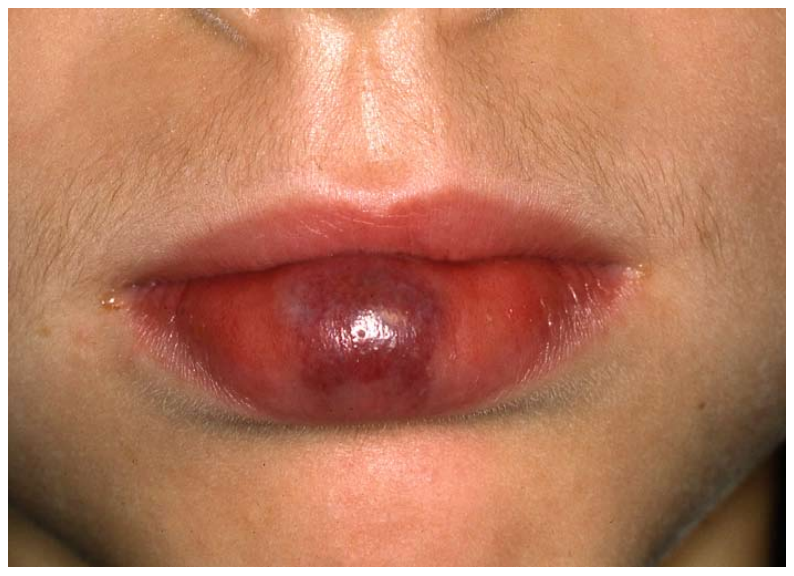

Fig. 1. Haemangioma in the lower lip.

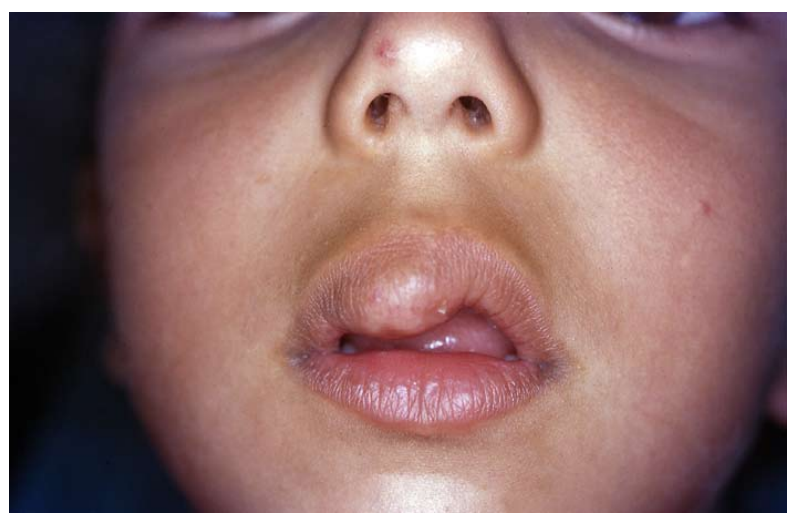

Fig. 2. Haemangioma in the upper lip.

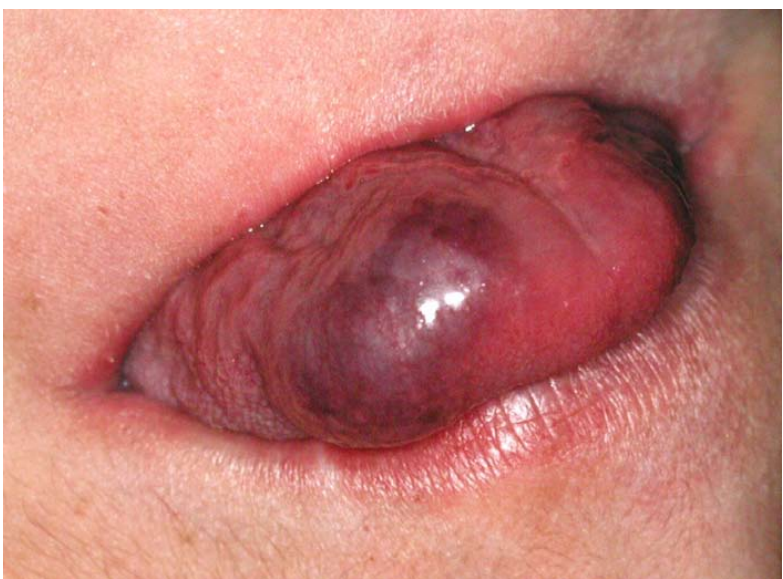

Fig. 3. Haemangioma in the tongue.

\section{Results}

Twenty-eight patients (19 girls and nine boys), aged 0 to 14 years, with an average age of 4.27 years were included in the study. Nine haemangiomas were diagnosed at birth (Table 2). The most common location was the lip, 13 in the lower (Fig. 1) and 10 in the upper (Fig. 2). The remaining sites were, 3 on the tongue (Fig. 3) and 2 in the buccal mucosa. The mean diameter of the lesion was $1.67 \mathrm{~cm}$ (range $1-3 \mathrm{~cm}$ ), and the mean duration 6.3 months (range 1 month to 5 years). Of the 28 haemangiomas, 13 were removed surgically, two were treated by embolization, and 13 disappeared spontaneously. The mean follow up was 2.7 months (1-8 months). There were no recurrences.

\section{Discussion}

Haemangiomas are benign vascular tumours common in childhood. Tanaka et al. (4) in 1999, assessed the maxillofacial tumours of 105 patients younger than 15 years. They found 25 oral haemangiomas (36.2\%), being the 
most common tumour in children. Corrêa et al. (10) in 2005 , studied the prevalence of oral haemangiomas in a Brazilian population; out of 2419 lesions, 22 cases were oral haemangioma $(0.9 \%)$, mostly in the adult population. Most haemangiomas are diagnosed at an early age (3). In this study we present 28 cases, representing one of the largest series of oral haemangiomas in children to date. Fourteen haemangiomas were diagnosed before 2 years of age, 9 of these at birth (Table 2).

With respect to gender, the literature $(6,10)$ shows a higher incidence in girls. In this study females were predominant, 19 girls and 9 boys.

Table 1 (3-9), shows that oral haemangiomas in children can reach up to $5 \mathrm{~cm}$ in size. In this study the mean diameter of the lesion was $1.67 \mathrm{~cm}$ (range $1-3 \mathrm{~cm}$ ).

In agreement with other authors (4-6), in this study the most common location was the lip, with 23 cases. Haemangiomas were found less frequently in the tongue and buccal mucosa. Lesions are not usually found in the tongue, and these can cause bleeding, pain and difficulty in chewing and in speech (11). In this study, 3 haemangiomas were located on the tongue.

Regarding treatment, corticosteroids have been used to reduce the size of the lesion $(6,7)$, embolization, and intralesional injections of sclerosing agents (8). For McHeik et al. (6), intralesional injection of corticosteroids may produce ulceration of the lesion. These same authors obtained very good results with surgical treatment of haemangiomas at an early age in cases with aesthetic problems or complications such as ulceration, pain, bleeding and infection. In this study, 13 were surgically removed, 2 were treated by embolization, and 13 disappeared spontaneously. Most congenital haemangiomas in this study (7 out of 9) regressed spontaneously without requiring treatment (Table 2).

Haemangiomas usually present in childhood, and can be seen from birth. They have a predilection for females and are uncommon in the oral cavity. In the oral region, the most frequent location is the lip. The majority of congenital haemangiomas regress spontaneously without needing treatment. The treatment of choice is surgical excision of the lesion.

\section{References}

1. Mulliken JB, Glowacki J. Hemangiomas and vascular malformations in infants and children: a classification based on endothelial characteristics. Plast Reconstr Surg. 1982;69:412-22.

2. Chin DC. Treatment of maxillary hemangioma with a sclerosing agent. Oral Surg Oral Med Oral Pathol. 1983;55:247-9.

3. Açikgöz A, Sakallioglu U, Ozdamar S, Uysal A. Rare benign tumours of oral cavity--capillary haemangioma of palatal mucosa: a case report. Int J Paediatr Dent. 2000;10:161-5.

4. Tanaka N, Murata A, Yamaguchi A, Kohama G. Clinical features and management of oral and maxillofacial tumors in children. Oral Surg Oral Med Oral Pathol Oral Radiol Endod. 1999;88:11-5.

5. Al-Khateeb T, Al-Hadi Hamasha A, Almasri NM. Oral and maxillofacial tumours in north Jordanian children and adolescents: a retrospective analysis over 10 years. Int J Oral Maxillofac Surg. 2003;32:78-83.

6. McHeik JN, Renauld V, Duport G, Vergnes P, Levard G. Surgical treatment of haemangioma in infants. Br J Plast Surg. 2005;58:106772 .

7. Van Doorne L, De Maeseneer M, Stricker C, Vanrensbergen R, Stricker M. Diagnosis and treatment of vascular lesions of the lip. Br J Oral Maxillofac Surg. 2002;40:497-503.

8. Selim H, Selim A, Khachemoune A, Metwally SA. Use of sclerosing agent in the management of oral and perioral hemangiomas: review and case reports. Med Sci Monit. 2007;13:CS114-9.

9. Kutluhan A, Bozdemir K, Ugras S. The treatment of tongue haemangioma by plasma knife surgery. Singapore Med J. 2008;49:e312-4. 10. Corrêa PH, Nunes LC, Johann AC, Aguiar MC, Gomez RS, Mesquita RA. Prevalence of oral hemangioma, vascular malformation and varix in a Brazilian population. Braz Oral Res. 2007;21:40-5.

11. Cohen SR, Wang CI. Steroid treatment of hemangioma of the head and neck in children. Ann Otol Rhinol Laryngol. 1972;81:584-90. 